\title{
The Factory Action and the Events at the Rosenstrasse in Berlin: Facts and Fictions about 27 February 1943 - Sixty Years Later
}

\author{
Wolf Gruner
}

$\mathrm{O}$ N 27 February 1943 in Nazi Germany the Gestapo brutally arrested more than ten thousand Jewish men and women. Martin Riesenburger, later the Chief Rabbi of the German Democratic Republic, recalled that day as "the great inferno." This large-scale raid marked the beginning of the final phase of the mass deportations, which had been under way since October 1941. Also interned in Berlin were people who, according to NS terminology, lived in so-called mixed marriages. But new documents show that no deportation of this special group was planned by the Gestapo. In the past decade, in both the German as well as the American public, quite a bit of attention has been paid to the fact that non-Jewish relatives publicly demonstrated against the feared deportation of their Jewish partners. The scholarly literature as well has pictured this protest as a unique act of resistance that prevented the deportation of these Jews living in mixed marriages. The fact that during this raid an untold number of Jews, both women and men, fled and went underground has so far been ignored. Since we still know much too little, the following article will discuss all the events of the spring of 1943 and their background. ${ }^{2}$

\section{Memory and History}

Since the beginning of the 1990s, this "successful" protest during the NS dictatorship has been commemorated in Germany annually. Especially in Berlin,

Translated by Ursula Marcum.

A German version of this article appeared in Jahrbuch für Antisemitismus Forschung (2002); 137-77.

1. Martin Riesenburger, Das Licht verlöschte nicht: Ein Zeugnis aus dunkler Nacht des Faschismus, $2 \mathrm{~d}$ ed. (1960); repr. East Berlin, 1984), 18.

2. For the basic arguments of this article see Wolf Gruner, "Die Reichshauptstadt und die Verfolgung der Berliner Juden 1933-1945," in Jüdische Geschichte in Berlin: Essays und Studien, ed. Reinhard Rürup (Berlin, 1995), 229-66, here 251-54; idem, Der geschlossene Arbeitseinsatz deutscher Juden: Zur Zwangsarbeit als Element der Verfolgung 1938 bis 1943 (Berlin, 1997), 311-26. For help and comments I am deeply grateful to Wolfgang Benz (Berlin), Beate Kosmala (Berlin), Konrad Kwiet 
the event is always remembered on the historical date of the "factory action," which will mark its sixtieth anniversary in 2003. A monument erected in 1995 in the Rosenstrasse, a small street in the center of Berlin where at the time hundreds of Jews from mixed marriages were interned in an adninistration building of the local Jewish Community, honors the event. ${ }^{3}$ Meanwhile, what happened sixty years ago has become a regular feature in the print media, ${ }^{4}$ the subject of documentary films, ${ }^{5}$ and discussion topics on the Internet. ${ }^{6}$ The message here is clear: if more people had behaved like the protesters, many deaths might have been prevented during World War II.

What did occur during those days? Over the years, a narrative has been created around the events of that time, concerning the course and the background of the "factory action" as well as the Rosenstrasse incident that was a part of it. The assumptions upon which this narrative is based will be discussed below. Until now, the main theses are as follows: at the time, the Gestapo had planned, in the course of the raid, to deport all Berlin Jews living in mixed marriages who, until then, had been considered "protected." It has been assumed that their internment was in preparation for their deportation. The public demonstration by their spouses in front of their place of internment, it is alleged, had prevented the deportation to Auschwitz of the Jews living in mixed marriages.

An examination of these theses reveals their long history. As early as December 1945 , shortly after the end of the NS dictatorship, Sie, the weekly for women and human rights, published an article by Georg Zivier under the terse title, "Aufstand der Frauen," (uprising of the women) in which the events of the end of February/beginning of March 1943 are described in the following manner:

The Gestapo had decided on a mass raid. The convoy of tarp-covered trucks stopped at the gate of the industrial plants. They also stopped in front of many private homes. Throughout an entire day, one could observe them driving through the streets, closely escorted by SS armed with rifles [...]. And the public failed to notice the lighting of a small torch that could have started a fire of general resistance against the arbitrary actions of tyrants. From the vast collection places where Berlin's Jewish inhabitants had been gathered, the

(Sydney), Claudia Schoppmann (Berlin), Stefanie Schuler-Springorum (Hamburg), Peter Witte (Hemer), and Susanne zur Nieden (Berlin).

3. The monument by the sculptress Ingeborg Hunziger had been commissioned by the DDR in 1989. On its dedication, see Berliner Zeitung, 19 October 1995.

4. Die Zeit, 21 July 1989, pp. 9-13; Der Spiegel 8 (1993): 58-68; Tagesspiegel, 23 February 1993,6 March 1993 and 5 March 1999; Berliner Zeinung, 28 February 1996, 28 February 1997, 28 February 1998, and 1 March 1999.

5. Die Rettung der Berliner Juden aus der Rosenstrasse (BRD 1993, producer: Hermann Schlenker); Befreiung aus der Rosenstrasse (BRD 1994, director: Michael Muschner). 2003, a U.S. documentary: Resistance of the Heart: Intermarriage and the Rosenstrasse Protest in Nazi Germany will appear (Pierre Sauvage with Nathan Stoltzfus).

6. See also "A teachers guide to the Holocaust" (http://fcit.coedu.usf.edu/Holocaust/timeline/rosenstr.htm), "Peacematters" (http://www.ppu.org.uk/peacematters/pm2(01/pm20101__ 91b.html); www.friedenspaedagogik.de, and www.frieden-gewaltfrei.de. 
secret police had singled out Jews with Aryan relatives and had brought them under special custody (Sondergetwahrsam) to the Rosenstrasse. What was to happen to them was totally unclear. It was then that the women intervened. They had found out where their men were kept. Early on the next day, and as if on cue, they appeared en masse in front of the improvised prison. The officials of the ordinary police (Schutzpolizei) tried in vain to push back or disburse the approximately six thousand demonstrators. They rallied again and again, pushed forward, called for their men - who, against strict orders, came to the window - and demanded their release. [. . .] The Gestapo headquarters were located in the Burgstrasse, not far from the place of the demonstration. The rebellious women could easily have been swept away by a few machine guns, but the SS did not shoot, not this time. Alarmed by an episode that during the period of the Third Reich had no parallel, one agreed to negotiations; one soothed, made promises, and eventually let the men go. ${ }^{7}$

Since the end of the war, the magazine Sie was published by Heinz Ullstein in Berlin. He had been interned in the Rosenstrasse and his wife had taken part in the protest. According to the Ullstein statement, he inspired Georg Zivier to write his article and even contributed to it. ${ }^{8}$ The journalist Ruth AndreasFriedrich was copublisher of Sie. She had kept a "diary," excerpts of which were published in the magazine in January 1946. She evidently made a relevant part of it available to Zivier and Ullstein for their article. Both texts, in their tone and in most details, show a striking similarity. Under 7 March 1943, AndreasFriedrich wrote in her diary:

The Jewish partners in racially mixed marriages. Separated from the others, one took them last Sunday to a collection point. For investigation and final resolution. On that very day the wives of these men set out to look for their arrested husbands. Six thousand non-Jewish women pushed into the Rosenstrasse, in front of the gates of the building where the Aryan-related were held. Six thousand women called for their men, screamed for their men, wailed for their men. Stood like a wall. Hour after hour. Night and day. The headquarters of the SS are in the Burgstrasse. Only a few minutes from the Rosenstrasse. In the Burgstrasse one was made uncomfortable by the situation. One did not consider it wise to fire machine guns at six thousand women. SS-leadership deliberation. The women are rebelling in the Rosenstrasse. Demand, menacingly, that their men be freed. At noon on Monday comes the decision from the headquarters of the SS: "Those in privileged marriages shall be returned to the Volksgemeinschaft." Those lucky enough to have married a non-Jewish partner may pack their bags and go home. ${ }^{9}$

7. See Die Wochenzeirung für Frauenrecht und Menschenrecht, 2d. ed. (Berlin, 1945), 1-2.

8. Heinz Ullstein, Spielplatz meines Lebens: Erinnerungen (Munich, 1961), 334-35, 340.

9. Ruth Andreas-Friedrich, Der Schattenmann (Frankfurt am Main, 1983), 103-4. It is possible that she wrote her diary in its present form also after the end of the war; see Helmut Peitsch, Deutschlands Gedächtnis an seine dunkelste Zeit: Zur Funktion der Autobiographik in den Westzonen Deutschlands und den Westsektoren von Berlin 1945 bis 1949 (Berlin, 1990), 300-3. 
The detached tone of the report suggests that Andreas-Friedrich herself was not an eyewitness to the event. But the diary as well as the magazine article already contained the most important ingredients of the story of the protest in the Rosenstrasse as it was remembered at that time. The historiographical key to today's prevailing view, therefore, is to be found as early as the immediate postwar period. The Zivier article was reprinted already in January 1946 in toto in the Neue Zeitung that appeared in Munich, Frankfurt am Main, and Berlin. The diary of Ruth Andreas-Friedrich was first published in 1947 in Germany and the U.S. and in 1948 in Great Britain. Repeatedly reissued, it is today one of the best-known testaments of the NS time. ${ }^{11}$ Knowledge of both texts not only influenced contemporaries who were questioned about the incident, it decisively formed the historiography of the events. In 1948 in the magazine Judaica, the Holocaust survivor and lawyer Bruno Blau asserted (without giving his sources but possibly aware of the newspaper account) that in February 1943 the Gestapo had planned a drive against the Jewish men living in mixed marriages, whose freedom, however, had been won through the public protest of their wives. ${ }^{11}$ While Raul Hilberg referred to the factory action in his standard text of 1961 on the persecution of the Jews, he did not mention the events of the Rosenstrasse. However, in 1992 he did address the protest in a book in connection with an article by Kurt Ball-Kaduri. ${ }^{12}$ Ball-Kaduri, first in an English scholarly publication in 1963 and later in 1973 in a German one, had written that in February 1943 the Gestapo had planned to stop exempting Jews living in "mixed marriages" from deportations. It was that plan against which the "Aryan" wives of the arrested men had demonstrated. The reference he cited was a postwar report by Ernst Gross. The latter, a 1943 inmate at the Rosenstrasse, referred to the fact that after 1945 newspapers had reported the event. His description relied to a considerable degree on the magazine article by Zivier, and Ball-Kaduri therefore excerpted and reprinted it in his own article. ${ }^{13}$

By the 1960s, as has been shown above, the account of a successful protest had already been widely accepted. In some historical works on the persecution of the Jews the topos now appeared without any citation of sources. ${ }^{14}$ In Germany,

10. Die Neue Zeitung: Eine amerikanische Zeitung für die deutsche Bevölkerning, 14 January 1946. p. 3. Ruth Andreas-Friedrich, Der Schattenmann (Frankfurt am Main, 1947); ibid., Berlin Linderground, 1938-1945 (New York 1947, London 1948).

11. Bruno Blau, "Die Mischehe im Nazireich," Judaica 4, no. 1 (Zurich, 1948), 46-57, here 53.

12. Raul Hilberg, Destruction of the European Jews (London, 1961), 277; idem, Tater, Opfer, Zuschauer: Die Vernichtung der Juden 1933-1945 (1992; repr. Frankfurt am Main, 1997), 151.

13. Kurt Jakob Ball-Kaduri, "Berlin is 'purged' of Jews: The Jews in Berlin 1943," Yad Vashem Studies 5 (1963): 271-316; idem, "Berlin wird judenfrei: Die Juden in Berlin in den Jahren 1942/1943," Jahrbuch für die Geschichte Mittel- und Osteuropas 22 (Berlin, 1973), 196-241 (the following uses the German edition).

14. Wolfgang Scheffler, Judenverfolgung im Dritten Reich 1933-1945 (Frankfurt am Main, 1965), 69; Robert M. W. Kempner, "Die Ermordung von 35,000 Berliner Juden: Der Judenmordprozess 
however, the event disappeared from the public discussion of the resistance. Both the tenor and the subject of this debate had changed since the end of the war. In the 1950s, some people in the Federal Republic openly denounced the resistance against National Socialism as treason. Although in the 1960s the public as well as the scholarly discussions - perhaps influenced by the NS trials - overcame this phase, the concept of resistance nevertheless narrowed to conservative (burgerliche) resistance. In 1964 the twentieth anniversary of the assassination attempt against Hitler was publicly honored. It would take another two decades, however, before other resistance groups, or other forms of opposition received scholarly attention and public interest in the Federal Republic. ${ }^{15}$

In the 1980s, many historians, in their descriptions of the factory action as well as their conclusions that a successful protest had occurred, referred to the Ball-Kaduri article. ${ }^{16}$ In some later or most recent discussions the topos can be found without any reference to sources or literature. ${ }^{17}$ The assertion of a planned deportation of Jews living in "mixed marriages" and its prevention even in the face of SS machine guns finally found its most fervent proponent in the 1990s in Nathan Stoltzfus who dedicated a book to the "Aufstand der Frauen," which was first published in the U.S. and later in Germany. Lately, several authors make reference to it in their work on the NS period. ${ }^{18}$ So far, two collections of contemporary witness reports and interviews have appeared in Germany. Gernot Jochheim presents the thesis of the successful protest in his

in Berlin schreibt Geschichte," in Gegenwart und Rückblick: Festschrift (Berlin, 1970), 180-205, here 202; Juden in Berlin 1671-1945: Ein Lesebuch, mit Beiträgen von Annegret Ehmann et al. (Berlin, 1988), 310 .

15. See Peter Steinbach, Widerstand im Widerstreit: Der Widerstand gegen den Nationalsozialismus in der Erimenung der Diutschen, 2d ed. (Paderborn, 2001).

16. See, for example, Monika Richarz, ed., Jüdisches Leben in Deutschland, vol. 3, Selbstzeugnisse zur Sozialgeschichte 1918-1945 (Stuttgart, 1982), 64; Konrad Kwiet and Helmut Eschwege, Selbstbehauptung und Widerstand: Deutsche Juden im Kampf um Existenz and Menschenwürde 1933-1945 (Hamburg, 1984), 43; Sybil Milton, "Women and the Holocaust: The Case of German and German-Jewish Women," in When Biology Became Destiny: Women in Weimar and Nazi-Germany, ed. Renate Bridenthal et al. (New York, 1984), 297-333, here 319; Claudia Koonz, Mothers in the Fatherland: Women, the Family, and Nazi Politics (London, 1986), 337.

17. Konrad Kwiet, "Nach dem Pogrom: Stufen der Ausgrenzung," in Die Juden in Deutschland 1933-1945: Leben unter nationalsozialistischer Herrschaft, ed. Wolfgang Benz (Munich, 1988), 545-659, here 594; Hermann Simon, "Die Zeit des Nationalsozialismus (1933-1945)," in Juden in Berlin, ed. Andreas Nachama, Julius H. Schoeps, and Hermann Simon (Berlin, 2001), 181-220, here 212; Georg M. Hafner and Esther Schapira, Die Akte Alois Brunner: Wanum einer der grösten Naziverbrecher noch immer auf freiem Fuss ist (Frankfurt am Main, 2000), 87-88.

18. Nathan Stoltzfus, Resistance of the Heart: Intermarriage and the Rosenstrasse Protest in Nazi Gemany (New York, 1996); idem, "Widerstand des Herzens: Der Protest in der Rosenstrasse und die deutsch-jüdische Mischehe," Geschichte und Gesellschaft 21 (1995): 218-47; idem, "Third Reich History as if the People Mattered: Eine Entgegnung auf Christof Dipper," Geschichte und Gesellschaft $26(20)(0): 672-84$

Marion A. Kaplan, Betueen Dignity and Despair: Jewish Life in Nazi Germany (New York, 1999), 193; Ian Kershaw, Hitler: 1936-1945 (Stuttgart, 2000), 1212, n. 115; Eric A. Johnson, Der nationalsozialistische Terror: Gestapo, Juden und gewönliche Deutsche (Berlin, 2001), 455-57. 
book, whereas Nina Schröder recently commented somewhat more cautiously. ${ }^{19}$ Only a few historians so far have questioned the prevailing interpretation. ${ }^{21}$

Today, the "successful" protest stands in the profession as much as a paradigm for nonviolent opposition as for the gender-specific resistance of women. Referring to the event, some authors have reached the conclusion that, had more people acted similarly, the deportations and extermination could have been stopped. Stoltzfus vehemently defends this opinion. ${ }^{21}$ This view also had its genesis shortly after the end of the war, for example in 1948 Bruno Blau wrote:

This behavior of the women shows that it was not impossible to fight successfully against the power of the Nazis. If a relatively small number of wives of Jewish men managed positively to influence the fate of their husbands, had they seriously wanted to, those Germans who now, and in such large numbers, proclaim themselves to have been against Nazism, could have prevented the atrocities that allegedly had not been desired by them, or more, that they abhorred. ${ }^{22}$

In the following, the historical events of the factory action in 1943 and in Berlin's Rosenstrasse as well as the background for the internment of Jews living in mixed marriages will be reconstructed and discussed. Contrary to earlier research that was based almost solely on survivor reports written many years later or on interviews conducted decades after the events, ${ }^{23}$ I have examined documents that have hitherto been ignored, i.e., from the Gestapo, Berlin's local police, Jewish institutions, and the Catholic Church, as well as early statements of survivors of 1945/46.

\section{The NS Leadership and the Decision to complete the Mass Deportations}

Toward the end of 1942, the deportation of Jewish Germans had already been completed in several regions of Germany. At that time, only 51,327 Jewish men

19. With a fictional report by Hans Grossmann compiled from diverse memories: Gernot Jochheim, Protest in der Rosenstrasse (Stuttgart, 1990), newly published as Frauenprotest in der Rosenstrasse: Gebt uns unsere Männer wieder (Berlin, 1993); Frauenprotest in der Rosenstrasse Berlin 1943: Berichte, Dokumente, Hintergründe (Berlin, 2001). With extensive interviews: Nina Schröder, Hitlers unbeugsame Gegnerinnen: Der Frauenaufstand in der Rosenstrasse (1998; repr. Munich, 2001).

20. Christof Dipper, "Schwierigkeiten mit der Resistenz," Geschichte und Gesellschaft 22 (1996): 409-16; Gruner, Arbeitseinsatz, 311-26; Peter Longerich, Politik der Vernichtung: Eine Gesamtdarstellung der nationalsozialistischen Judenverfolgung (Munich, 1998), 537; Beate Meyer, "Jüdische Mischlinge“: Rassenpolitik und Verfolgungserfahrong 1933-1945 (Hamburg, 1999), 57.

21. See Ball-Kaduri, 214; Kwiet and Eschwege, Selbstbehauptung, 43; Kwiet, Pogrom, 594; Schröder, Gegnerinnen, 57; Jochheim, Frauenprotest (1993), 27-28, 136. Stoltzfus, Aufstand, 345. He was joined here by Daniel J. Goldhagen, Hitlers willige Vollstrecker: Ganz gewihnliche Deutsche und der Holocaust (Munich, 1996), 151.

22. Blau, Mischehe im Nazireich, 53-54.

23. Testimony from the Berlin Gestapo-trial of the 60 s is available, which Stoltzfus uses, as well as interviews from the 80s and 90s, on which Stoltzfus, Jochheim, and Schröder base their work. 
and women remained in Germany proper, concentrated in some big cities such as Berlin and Breslau and, what is less well-known, in dozens of work camps. The majority of them, according to an SS statistic altogether 20,406, were forced laborers working in industry. In Berlin alone, probably two hundred businesses still employed fifteen thousand Jews. During 1942, therefore, Hitler had repeatedly demanded that Jewish forced laborers be removed from the armaments industry in the Reich. ${ }^{2+}$

The deportation of the remaining workers and their families began, according to contemporary estimates, in December 1942. At that time, the officials of the Reichssicherheitshauptamt (RSHA) apparently made concrete preparations to bring the mass deportations that had been underway since October 1941 to a close. However, too few Polish workers arrived in the Reich quickly enough to replace the Jewish forced laborers. Additional difficulties arose due to transportation delays in the General Gouvernement. It is possible that as a result, further deportations were postponed until the following spring. At the beginning of December 1942, the Berlin industrial concerns were informed that the deadline for the departure of the forced Jewish laborers was 31 March 1943. ${ }^{25}$

In early 1943 hundreds of thousands of foreign workers arrived monthly in the industrial centers, and the NS leadership seemed to have sufficient replacements for the Jewish forced laborers. On 22 January 1943, Goebbels urged Hitler to speed up the deportations. In the face of the debacle threatening Germany at Stalingrad, both were united in the desire to bring the "Jewish Question" to a conclusion in Germany proper, and especially in Berlin, "as fast as possible (schnellstmöglich)." After the defeat, Hitler himself ordered all NSDAP Reich- and Gauleiter "to be ruthless [...] toward Jews." ${ }^{26}$ Since the enemy abroad and within merged now in the transition to "total war" the decision for a concrete date for the last deportations was made.

On 18 February Goebbels noted that, with the target date of 28 February, Berlin's Jews would "first be gathered in camps" and then deported in batches of up to 2,000 people a day. ${ }^{27}$ Only two days later, on 20 February, the Reichssicherheitshauptamt issued the general "instructions for the technical implementation" of the last large deportation wave in the Altreich. All Jews, including the forced laborers in firms essential to war production, would be deported, with the exception of those living in mixed marriages. ${ }^{28}$ Shortly

24. Gruner, Arbeitseinsatz, 299-307.

25. Ibid., 311 .

26. Elke Fröhlich, ed, Die Tagebücher des Joseph Goebbels, part 2, Diktate 1941-1945, vol. 7 , Janwary-March 1943 (Munich, 1993), 177: entry of 23 January 1943. Ibid., 295-97: entry of 8 February 1943. It should be noted that Kershaw points to a renewed interest in the Jewish question by Hitler only at the beginning of April 1943; Kershaw, Hitler: 1936-1945, 759.

27. Tagebuicher von Joseph Goebbels, part 2, vol. 7, 369: entry of 18 February 1943.

28. BA Berlin, Zeitgeschichtliche Sammlung 138, unfol.; excerpt in $\mathrm{H}$. G. Adler, Der verualtete Mensch: Studien zur Deportation der Juden aus Deutschland (Tübingen, 1974), 199-200. 
thereafter the RSHA issued orders to the Gestapo in the Reich that established the concrete process of a large-scale raid in factories and industries. This raid, however, was not exclusively directed against the "fully Jewish" forced laborers who were to be deported, but the RSHA ordered, as shown in a - to this day ignored - order of the Gestapo Frankfurt/Oder, to remove all Jews still working in factories, including also those "living in mixed marriages," although the latter were not to be deported. In view of the unprecedented nature of this action, the order carried the notice "no precedent":

The Reichssicherheitshauptamt in Berlin had ordered that, since virtually all the Jews who had resided in this district, with the exception of those who live in German-Jewish mixed marriages, have almost all been resettled, all Jews still working in factories are to be removed from their workplace and assembled. This pertains in particular to those Jews living in mixed marriages. Any protests on the part of managers are to be politely rejected with the statement that this measure is being carried out with the approval of the armaments command and those offices responsible for the workforce and production.

The factory managers will be informed by the local labor office, which will also handle replacements. The collection of the Jews working in German businesses is to be carried out unobtrusively, possibly through the use of the factory security personnel. Attention is to be paid, however, that transgressions and attempts to escape during this raid on the part of Jews are to be avoided. Under no circumstances must there be any overstepping of authority on the side of officials or of those charged with guarding (the Jews), especially not in public or within the area of the business itself. Any impudent behavior by Jews who still live in existing mixed marriages is to be dealt with by taking them into protective custody and requesting that they be sent to concentration camps. One may proceed "generously" here, however. The impression must be avoided that one of the purposes of this raid is once and for all to solve the problem of mixed marriages. Insofar as there are no reasons to justify the arrest of Jewish spouses living in a mixed marriage, they are to be released to their home. In no case must they again be employed in this or any other firm. Further instructions regarding their future utilization will follow [...] By order of the Reichssicherheitshauptamt, the raid is to be conducted promptly on 27 February 1943 at the start of work. It is advisable that the officials carrying out the raid be furnished with written instructions to be handed to the plant managers that state something to the effect that the official is authorized to remove all Jews from the factories in order to register them. ${ }^{29}$

The order was signed by the SS Hauptsturmfuihrer and Regierungsassessor Reinhard Wolff, who was born in 1909 in Chemnitz and since April 1941 was

29. Erlass, 24 February (II B 4-1958/42) in Erlass des Landrats in Calau, 25 February 1943; Brandenburgisches Landeshauptarchiv (hereafter BLHA) Potsdam, Pr. Br. Rep. 41 Grossräschen, no. 272 , fols. $84-85$. 
the chief of the Stapoleitstelle Frankfurt/Oder. It was obviously a much modified and extended version of the RSHA orders, especially as those Jews living in mixed marriages were named as the targets of the action, a fact that could apply only to places outside of Berlin, where most other Jews had already been deported.

The RSHA orders were transmitted on 24 February by the Gestapo at Frankfurt/Oder to the Landräte of the government district (Regierungsbezirk), that is three days before the planned raid, in order to allow sufficient time to inform all relevant offices, as far as they had not already become aware of it through other channels, of the dual aim of an, as the order stated, "evacuation or removal of Jews from factories." The Generalbevollmächtigte for labor, Fritz Sauckel, also advised the district labor offices about the planned actionalthough only those "in whose districts greater numbers" of German Jews were still forced to work, in order "not to endanger the measure's element of surprise." On 25 February the Gestapo in Bielefeld accordingly ordered a work ban for Jews in a number of city and county districts. On 26 February, the Gestapo in Dortmund also issued to district officials and mayors "ohne Vorgang" (no precedent) the order that, as of 27 February, Jews still working "were to be removed" from their jobs for the purpose of their "partial [teilweisen] evacuation to the east." ${ }^{\text {"II }}$ The Gestapo sources thus explained the double aim of the action: deportation of the "unprotected" Jews as well as removal of the still "protected" Jews from their places of work, not only in Berlin but in the entire area of the Reich. Today this great raid is known and notorious under the name of "factory action," a term that was apparently already coined during the war or shortly thereafter by the persecuted themselves. The term is not present in any of the official documents of the time, but was used as early as $1945 / 46$ in Berlin in letters to the Berlin municipal offices by survivors. ${ }^{31}$

\section{The Factory Action in Berlin and in the Reich}

It is now possible to reconstruct the course and dimension of the notorious raid with much greater accuracy than in the past. When the mayors of the regions received the orders of the Dortmund Gestapo on 26 February, the inmates of several forced-labor camps for Jews were told to report next day to Dortmund to have their work papers examined. When they arrived there, they

30. Mentioned in: Sauckel an die Landesarbeitsämter, 26 March 1943 (Nürnberg Dok. L-156), in Nazi Conspiracy and Aggression (Washington, 1946), 7: 905. Margit Naarmann, Die Paderborner Juden 1802-1945: Enanzipation, Integration und Vernichtung: Ein Beitrag zur Geschichte der Juden in Westfalen im 19. und 20. Jahrhundert (Paderborn, 1988), 353. Polizeiarchiv Dortmund, B 1802, fols. 20102: Gestapo-order of 26 February 1943, sent with letter of Landrat von Meschede, 1 January 1943.

31. Cf. Archiv der Stiftung "Neue Synagoge Berlin-Centrum Judaicum" (hereafter CJA) Berlin, 4.1 , no. 81 and 208 , unfol. The terms Schlussaktion or Judenschlussaktion frequently used by Stoltzfus and also by German dailies are apparently word creations from postwar trials against the Berlin Gestapo; see Stoltzfus, Aufstand, 397, n. 3. 
were taken into custody by the Gestapo and housed in a Gasthaus where, during the days of the raid, all Jewish men and women, old people as well as children from Dortmund and its environs were brought together. At the camp for Jews in Paderbom, people also heard of the termination of their forced labor on the evening of 26 February. The local Gestapo received the order from Münster to deliver the camp inmates to Bielefeld together with Jews from Haarm and Westheim, an order they carried out on the morning of 1 March. ${ }^{32}$

The men and women in the forced-labor camps, at least in Brandenburg if not throughout the Reich, were actually to be exempted from the measure for the time being, for the order cited above of the Frankfurt/Oder Gestapo read: "The Jews employed in business firms, as long as they live in closed camps such as Neuendorf i. S. and camps for forestry work, etc., are not to be included in this raid.' It seems that this instruction apparently was not uniformly followed. Whereas for Jewish inmates of a whole series of work camps in Brandenburg (for example in Hangelsberg, Kaisermühl, Kersdorf, and Neuendorf) there remained a grace period of a good month before their deportation, the camps Gut Winkel and Skaby were emptied on 27 February in the course of the raid, as was the Silesian camp of Gross Breesen. The Silesian camps Grüssau and Riebnig, where Jewish families had been ghettoized since the summer of 1941 , were also disbanded. ${ }^{33}$ In Dresden, the last "unprotected" Jews who had lived in the forced-labor camp Hellersberg for three months were told that it was now shut down. The great raid rounded up, in addition to inmates in work camps, the last Jews still living in their hometowns. They were now brought together in larger cities. The Jews from Halle/Saale, Leipzig, Plauen, Chemnitz, and Erfurt, for example, were brought to Dresden. While in the cases discussed so far the preparations for deportation were handled pretty close to the "customary" "Gestapo pattern, the process in the cities where still a greater number of Jews lived was quite different. In Breslau, hundreds of Jews were arrested in their homes by the Gestapo and the ordinary police and crammed into three collection points. ${ }^{34}$

32. Helga Tröster, "Geschichte und Schicksal der Juden in Schmallenberg," Schmallenberger Heimatblatter, 55 (1983-1985): 51-102, here 94b; Irmgard Harmann-Schütz and Franz BlomeDrees, Die Geschichte der Juden in Sundern: Eine geschuldete Erimnernng an die Familic Klein (Sundern, 1988), 85; Hans Frankenthal, Venweigerte Rückkehr: Erfahnungen nach dem Judesmord, 2d ed. (Frankfurt am Main, 1999), 43-46. Naarmann, Die Paderboner Juden, 352-53.

33. Gruner, Arbeitseinsatz, 267-69.

34. Markus Gryglewski, "Zur Geschichte der nationalsozialistischen Judenverfolgung in Dresden 1933-1945," in Die Erinnerung hat ein Gesicht: Fotografien und Dokumente zur nationalsozialistischen Judenverfolgung in Dresden 1933-1945, ed. Norbert Haase, Stefi Jersch-Wenzel, and Hermann Simon (Leipzig, 1998), 87-150, here 138-40, 178. See Victor Klemperer, lch will Zeugnis ablegen bis zum letzten. Tagebücher, vol. 2, 1942-1945, 2d ed., ed. Walter Nowojski (Berlin, 1995), 2:334-40. Karol Jonca, "Die Deportation und Vernichtung der schlesischen Juden," in Die Normalitat des Verbrechens: Bilanz und Perspektiven der Forschung zu nationalsozialistischen Geualtverbrechen. Festschrift für Wolfgang Scheffler zum 65. Geburtstag, ed. Helge Grabitz et al. (Berlin, 1994), 156-61. 
Although in most of the places in the Reich the raid lasted only one or two days, in Berlin, where still more than ten thousand forced laborers and their families lived, it took a week. On Friday, 26 February, the Gestapo in Berlin ordered the Jewish Community to have several groups ready for the next day for administrative duty and for the care of the sick. Furthermore, the factories that still employed Jewish forced laborers were informed of the orders ${ }^{35}$ At about 8 o'clock on Saturday morning, the precincts of the Berlin police were alerted by radio message from the headquarters of the state police about a "Grossaktion Juden." They were directed to take into custody any Jews seen on the street or in their districts and to deliver them to specifically established collection points. The city police were told at the same time that a camp was set aside in the Rosenstrasse for those Jews related to Aryans (arisch Versippte). ${ }^{36}$ Due to the enormous number of Jews to be removed, the Berlin Gestapo conducted the raid with the assistance of the Waffen SS. ${ }^{37}$ The Gestapo was responsible for the selection of the deportees, the SS to secure the arrests and the transports. The raid was carried out in the early morning at the start of work in probably more than one hundred Berlin business establishments. In the factory of the firm Hellmuth Korth (precision and optical microscopic instruments), twenty-five Jewish forced laborers had to line up in the courtyard, "then a civilian, apparently a member of the Gestapo, approached us and checked our names on a list." ${ }^{38}$ One of the Jewish forced laborers, Manfred Keins, died of a heart attack during the raid. ${ }^{39}$ Notwithstanding the February cold, the arrested were transported in trucks dressed only in their thin work smocks. The raid, however, was not limited to the arrests at the workplaces. Those forced laborers of all firms who had finished their shifts on Friday night and were therefore not physically present in the factories were arrested in their homes together with their families

35. Hildegard Henschel, "Aus der Arbeit der jüdischen Gemeinde Berlin während der Jahre 1941-1943: Gemeindearbeit und Evakuierung von Berlin, 16 Oktober 1941-16. Juni 1943," Zeitschrift für die Geschichte der Juden 9, nos. 1 and 2 (1972): 33-52, here 46. Archiv der Staatsanwaltschaft beim Landgericht (hereafter AS LG) Berlin, Js 9/65 Bovensiepen-Verfahren, ZH 75, fols. 5-6: Witness interrogation of Gerda Kühnel, 30 September 1966.

36. The radiogram was not available to me, but is mentioned in several police diaries. It said e.g., "laut Fs. Stl. Nr. 5620 v. 27 February 1943. 08,16 Uhr"; Landesarchiv Berlin (hereafter LAB), B Rep. 020, Acc. 1124, no. 6941, unfol.: 173. Revier, entries no. 158-160 of 27 February 1943; ibid., Acc. 5179, Nr. 8496, fols. 241: 205. Revier Tempelhof, entries no. 53-54 of 27-28 February 1943; see ibid., Acc. 1093, no. 6937, fols. 81-82: 129. Revier Charlottenburg, no. 89-90, of 27 February and 1 March 1943. Report of Charlotte Israel in Landesbildstelle Berlin, ed., Die Grunewald-Rampe: Die Deportation der Berliner Juden, 2d ed. (Berlin, 1993), 147. See report Gad Beck bei Schröder, Gegnerinnen, 147.

37. The memoirs name the Leibstandarte SS „Adolf Hitler," which at the time was fighting in the Soviet Union. The replacement units are obviously meant. I thank Dieter Pohl (Munich) for the tip.

38. AS LG Berlin, Js 9/65, ZH 110, fols. 11: witness interrogation Curt Radlauer, 10 November 1966.

39. LAB Rep. (120, Acc 5179, no. 8496, fols. 240-41: 205. Revier Tempelhof, entry no. 52, 27 February 1943. 
on February 27. Many Jews met this fate after having been summoned to the labor office or to police stations. People wearing the Jewish star were likewise just stopped in the street and taken to the collection points. ${ }^{. \prime}$

In order to house eight thousand arrestees, the Gestapo used military barracks in Berlin Reinickendorf, and in Moabit, the ballroom "Clou" in district Mitte, and in addition the synagogue in the Levetzowstrasse (Moabit) and the smaller buildings of the Jewish Community in the Gerlachstrasse and Grosse Hamburg Strasse, both in Berlin Mitte. Those arrested in district Charlottenburg were taken to the synagogue at Levetzowstrasse, designated officially as Camp II of the great raid; those from Tempelhof among others went to the "Clou," Camp IV."1

For the time being, employees of the Jewish Community and those working for the Reichsvereinigung der Juden in Deutschland and their families were considered protected, and if arrested, were soon let go. They had been issued "yellow passes" before the action began. Nanny Behrend, whose husband was employed by the Reichsvereinigung was detained at her place of work, but was freed after one night in the camp Levetzowstrasse. On the following day, her husband was stopped during a street raid but was also freed after a night at the Levetzowstrasse. Only during the day of 27 February did the Jewish Community receive permission to supply the victims of the raid with food. Because of transportation problems, many did not get anything to eat until the evening of the next day. In the crowded collection points, where sanitation conditions were deplorable, the inmates lived through the first heavy aerial bombardments of Berlin during the evening of March 1 without any kind of protection. ${ }^{42}$

40. Anonymous report from Lausanne, late 1943, in Mira Schoenberner and Gerhard Schoenberner, Zeugen sagen aus: Berichte und Dokumente über die Judenverfolyng im Dritten Reich (East Berlin, 1988), 326-27. Report Gad Beck in Frank Heibert, ed., Und Gad ging zu David: Die Erinnerungen des Gad Beck 1923 bis 1945 (Berlin, 1995), 96-97. LAB, B Rep. 020 Acc. 1124, no. 6941, unfol.: 173. Revier Schöneberg, entry no. 159 of 27 February 1943; ibid., Acc 5179, no. 8496, fols. 241-42: 205. Revier Tempelhof, entry of 28 February 1943; report Charlotte Israel, in Grunewald-Rampe, 147. LAB, B Rep. 020, Acc. 1124, no. 6941, unfol.: 173. Revier, entries no. 158 and 160 of 27 February 1943. copy of no. 158, in Jiidische Geschichte in Berlin: Bilder und Doktmente, ed. Reinhard Rürup (Berlin, 1995), 323.

41. See YV Jerusalem, 01, no. 51, unfol: Moritz Henschel „Die letzten Jahre der jüdischen Gemeinde Berlin“ (1946), 4; Henschel, Arbeit, 47; Leo Baeck Institute/Archive (hereafter LBI/A) New York, Memoir Coll.: Martha Mosse "report 23-24 July 1958," 13; Schoenberner and Schoenberner, Zeugen, 326-27; report Kahan in Dagmar Hartung von Doetinchen, "Zerstörte Fortschritte: Das Jüdische Krankenhaus in Berlin 1756-1861-1914-1989," in Zerstorte Fortschritte, ed. Rolf Wienau (Berlin, 1989), 75-215, here 190. LAB, B Rep. 020, Acc. 1093, no. 6937, fols. 81-84: 129. Revier Charlottenburg, no. 89-90,94, 27 February to 5 March 1943. Ibid., Acc. 1124, no. 6941, unfol.: 173. Revier Schöneberg, no. 158-60, 27 February 1943; ibid., Acc. 5179, no. 8496, fols. 241: 205. Revier Tempelhof, no. 53, 27 February 1943.

42. Henschel, Arbeit, 45-47. Letter of Ernst Behrendt, 2 March 1943, in „Wir verreisen ... “in die Vernichtung: Briefe 1937-1944, ed. Hanne Hiob and Gerd Koller (Hamburg, 1993), 112. Report in Schoenberner and Schoenberner, Zeugen, 326-27; report Frau Kahan; Hartung von Doetinchem. Zerstörte Fortschritte, 190. 
For days after the raid, people still at large or those having escaped from the Gestapo and the security police were being hunted down. Fearing deportation, many committed suicide. The daily $\log$ of police district 173 in BerlinSchöneberg alone registered a dozen suicides during these days, among them the couple Jacobi on 8 March 1943, after their neighbor had been "evacuated." Some chose suicide while still at the collection camps, for instance Stella Rauh who poisoned herself with sleeping tablets at the synagogue Levetzowstrasse died at the Jewish hospital on March 1. Disregarding the orders of RSHA, SS men beat the Jewish victims when they picked them up at their work places, when they delivered them to the collection points, and when the victims were loaded for deportation. ${ }^{43}$

The first transports to Auschwitz were already being assembled while the raid in Berlin was still in progress. For instance, on 1 March 1943, smaller transports left Düsseldorf, Dortmund, Frankfurt am Main, and Trier. ${ }^{4+}$ During the night from 2 to 3 March, hundreds of Jews from Bielefeld and Dresden were taken away. ${ }^{+5}$ On 4 or 5 March a train left with hundreds of Jews from Breslau. ${ }^{4 h}$ According to figures available so far, within six days, approximately seven thousand people were deported from Berlin. In quick, almost daily succession, five transports left the capital: on 1 March with 1,722 persons, on 2 March with 1,756, on 3 March with 1,776, on 4 March with 1,120, and on 6 March with $664 .^{47}$

During the first days of March the SS in Auschwitz registered a total of eight large transports. Seven were listed as transports of RSHA from Berlin, one each

43. Henschel, Arbeit, 49. See LAB, B Rep. 020, Acc. 1093, no. 6937, fols. 82: 129. Rev. Charlottenburg, no. 89-90 of 28 February-1 March 1943. Ibid., Acc. 1124, no. 6941, fols. 54-73: 173. Revier Schöneberg, entries of 28 February-9 March 1943. Ibid., Acc. 1124, no. 6941, fols. 54-73: 173. Revier Schöneberg, entries of 28 February-9 March 1943. Report Erika Lewin in Schröder, Gegnerinnen, 115; letter Rudolf aus den Ruthen (Schwarzes Korps) to Brandt (RFSS) on 4 March 1943, in Scheffler, Judenverfolgung, 69. See LBI/A New York, Memoir Coll.: "Bericht 23-24 July 1958" of Martha Mosse, 13; Adler, Mensch, 227-28.

44. Holger Berschel, Biurokratie und Terror: Das Judenreferat der Gestapo Düsseldorf 1935-1945 (Essen, 2001), 363; Frankenthal, Venveigerte Rückkehr, 43-46; Monica Kingreen, "Gewaltsam verschleppt aus Frankfurt: Die Deportationen der Juden in den Jahren 1941-1945," in Nach der Kristallnach: Jiidisches Leben und antiiüdische Politik 1938-1945 in Frankfurt am Main, ed. Frankenthal (Frankfurt am Main, 1999), 357-402, here 387; Roland Müller, Stuttgart zur Zeit des Nationalsozialismus (Stuttgart, 1988), 409; Paul Sauer, Die Schicksale der juidischen Bürger BadenWürttembergs während der nationalsozialistischen Vevfolgungszeit 1933-1945 (Stuttgart, 1969), 393; Reiner Nolden, ed., Juden in Trier: Katalog einer Ausstellung von Stadtarchil und Stadtbibliothek Marz-November 1988 (Trier, 1988), 127.

45. Joachim Meynert, Was vor der „Endlösung" geschah: Antisemitische Ausgrenzung und Verfolgung in Minden-Ravensberg 1933-1945 (Münster, 1988), 246, 263; Gryglewski, Judenverfolgung, 138-40, 178.

46. Jonca, Deportation, 156; see Adler, Mensch, 228.

47. Freie Universität Berlin, Zentralinstitut für sozialwissenschaftliche Forschung, ed., Gedenkbuch Berlins der jüdischen Opfer des Nationalsozialismus: Ihre Namen mögen nie vergessen werden! (Berlin, 1995), 1420. Compare to other numbers in Wolf Gruner, "Judenverfolgung in Berlin 1933-1945: Eine Chronologie der Behördenmassnahmen in der Reichshauptstadt," ed. Reinhard Rürup (Berlin, 1996), 99. 
from Breslau, Berlin, and other cities. The figures of passengers, however, do not match in all cases those until now available for Berlin. Since no separate transports from West German cities arrived in Auschwitz, one must assume that the Gestapo added these victims to the Berlin transports. ${ }^{18}$ Altogether in the few days of the factory action the Gestapo deported 10,948 Jewish women and men, approximately two thirds from Berlin and the other third from the rest of the Reich. ${ }^{+9}$ That number, however, was four thousand less than the fifteen thousand armament workers whose arrival the SS Wirtschaftsverwaltungshauptamt had announced to the KZ Auschwitz at the beginning of March for Berlin alone. Since the WVHA of the SS, however, was not directly involved in the deportations, it apparently worked with the above given numbers of forced laborers from the end of 1942 that showed fifteen thousand for Berlin, a number no longer correct after the stepped-up transports of January and February. Although the number of victims arriving at Auschwitz was much smaller than expected, and in spite of the order from WHVA to put them to work at the Buna plants in Auschwitz-Monowitz, the majority was immediately gassed. ${ }^{5 .}$

\section{Flight and Resistance}

The office for armament inspection for Wehrbezirk III Berlin noted on 27 February 1943 that the departure of all Jews who had still been employed "had taken place and that, as a result, eleven thousand fewer forced laborers were now available." ${ }^{51}$ That number included not only those deported from Berlin and those removed from factories who belonged to the group of Jews living in mixed marriages who were not slated to be deported, but apparently thousands of male and female forced laborers who had fled before the raid started. Until now, this fact has not been sufficiently considered or appreciated.

Propaganda Minister Goebbels had angrily recorded in his diary: "That the Jews were to be arrested within one day turned out $[\ldots]$ to have been like a slap on water. We failed, overall, to grab four thousand Jews. They now rove about Berlin without living quarters, unregistered, and of course represent a great danger to the public." 52 Planning and preparation for the raid had alerted

48. Danuta Czech, Kalendarium der Ereignisse im Konzentrationslager Auschuitz-Birkenan 1939-1945 (Reinbek bei Hamburg, 1989), 427-34; as well as cable of 8 March 1943 to WVHA, in Reinhard Rürup, ed., Topographie des Terrors: Gestapo, SS, und Reichssicherheitshatuptamt anf dem „Prinz-Albrecht-Gelände": Eine Dokumentation (Berlin, 1989), 119.

49. Altogether in March 1943 the number of deportees are as follows: from Silesia 1,788, from Central Germany 404, from Northwest Germany 413, from Westphalia 547, from Bavaria 217, from the Rhineland 201, from Brandenburg/East Prussia 171, from Hesse 50, and from Southwest Germany 41; BA Berlin, R 8150, no. 69, fols. 57: RV-Statistik for March 1943.

50. Chief of Zentralamt to Höss 2 March 1943; Publ. in Jochheim, Fraut'ruprotest (1993), 122. See Czech, Kalendarium, 428.

51. War diary Rüstungsinspektion III, 27 February 1943; published in Kwiet, Pogrom, 592.

52. Tagebücher von Joseph Goebbels, part 2, 7:528: entry of 11 March 1942. 
many men and women to the impending danger and had made them decide to go underground. The orders of the RSHA after all circulated for several days within the police and administration. The Gestapo cooperated both with the SS and the ordinary police, as well as with the military office for armaments inspection. The business firms had been informed and plant security forces had been mobilized. Days before, detailed information of the "planned raid" was also available in the ministries. ${ }^{53}$

On the basis of such information, countless people in Berlin were aware of the impending great raid. Many of them warned potential victims. Goebbels remarked twice in his diary that the raid had been prematurely leaked. On 2 March, he accused the intellectuals and on 11 March, the industrialists. ${ }^{5+}$ Walter Besser, who worked as a forced laborer for the firm Naumann in Berlin recalled that, already in the middle of February, members of the military who were inspecting the arms productions said to him: "We are sorry that all Jews are to be taken into custody. [ . . ] Can't you go underground somewhere?" Fourteen days later they came back and, thanks to good connections to the Gestapo, they had learned the target date. "You must be gone within three days. On that [...] day the great raid will take place. That is on the 27th of February." 55 Walter Besser did go into hiding and survived. In most cases forced laborers received the actual tip from workers, supervisors, white-collar employees or engineers in their companies, at times even from the police or from acquaintances in the SS. ${ }^{56}$ For days rumors circulated about impending "measures against Jews in Berlin," according to an employee of the Jewish Community. "Police officials cautiously mentioned that on 27 and 28 February 1943 there would be actions against the Jews. ${ }^{57}$ Many Jews heeded the warnings and fled, some did not go to work on the day of the raid. Chance also played a role. Günter Fabian stayed home on that day because on the previous day the low paycheck for his forced labor had angered him. His fiancée and her family, who did go to their shift, were deported. ${ }^{5 \rtimes}$ A few managed to escape even as the Gestapo searched the firms. ${ }^{59}$

53. Cf. copy of undated letter (approx. beginning of March 1943) in Akten deutscher Bischöfe iber die Lage der Kirche 1933-1945, vol. VI: 1943-1945, ed. Ludwig Volk (Mainz, 1985), Dok. 817, 19-21. I am grateful to Rainer Decker (Paderborn) for pointing out this source.

54. Tagebticher von Joseph Guebbels, part 2, 7:449, 528: entries 2 and 11 March 1943.

55. Interview of author with Walter Besser, 2 Apr. 1990, 13. In a published report of Besser, going underground is given as 15 February, but it seems that 25 February is meant; report in Wolfgang Herzberg, Uberleben heisst Erinnem: Lebensgeschichten deutscher Juden (Berlin, 1990), 239-42.

56. See LBI/A New York, AR 7183, Max Kreutzberger Research Papers, Box 8, Folder 2: „Untergetaucht“ von Susanne Veit, 2; Kaplan, Dignity, 202 LAB, Rep. 057-01, no. R34/34, fols. 1: witness interrogation, 26 March 1965 (Bovensiepen-Prozess); Michael Degen, Nicht alle waren Mirder: Eine Kindheit in Berlin (Munich, 2001), 23.

57. AS LG Berlin, 3 P Ks 1/71, vol. XXXVI, fols. 94: witness interrogation Karl Hefter, 3 February 1956, 1. See ibid., vol. XVIII, fols. 20: witness interrogation Otto Fried, 13 April 1966. See also Degen, Morder, 24.

58. Interview by the author with G. Fabian, 22 January 1991, 5.

59. Report Kurt Lindenberg, in Schoenberner and Schoenberner, Zetugen, 319-22. 
The fact that so many Jews went underground contradicts the still widely accepted picture that they allowed themselves to be led as "sheep to slaughter." If in Berlin four thousand disappeared and seven thousand were deported that means that every third person designated by the Gestapo to be deported avoided deportation. This achievement meant that the potential victims took decisive action to avoid being murdered. The founding of the Jewish resistance group "Chug Chaluzi" as late as the evening of 27 February symbolizes this fact most clearly. Even in the underground they joined forces in order to help other "illegals." Although later on many of the "U-Boote" (submarines) would be caught by the Gestapo, a considerable number of them managed to save themselves until the end of the war and so survived. We still know much too little about these Jewish men and women who used their "going underground" as the most effective form of individual resistance against the persecution and about the many non-Jewish Germans who displayed civic courage by alerting those about to be seized and helping them to hide. ${ }^{61}$

\section{The Jews in Mixed Marriages and the Internment in the Rosenstrasse}

On the day of the great raid those Jewish forced laborers who lived in "mixed marriages" were also removed from the industrial plants. At the time, many understood this to be a clear signal that the entire group was also marked for deportation. In Dresden Victor Klemperer noted on the day of the factory action that, "Lewinsky of the Jewish Community" had warned in despair: "All of us will be summoned and immediately detained -- the privileged included." 22 Were the Jews from mixed marriages after all also to be deported? In the SS leadership the fate of the "Aryan-related" had long been discussed without a decision being reached. ${ }^{63}$ Beginning with the mass transports in October 1941 they were, temporarily (vorläufig), exempted from deportations. ${ }^{\text {fi }}$ At the Wannsee Conference on 20 January 1942, RSHA Chief Reinhard Heydrich discussed "for now only theoretically" the deportation - after consideration on a case-by-case basis - of Jews in mixed marriages. However, what the NS leadership lacked as a pseudo-legal basis for such an action was a law

60. See Christine Zahn, "Nicht mitgehen, sondern weggehen!" Chug Chaluzi - eine jüdische Jugendgruppe in Untergrund," in Juden im Widerstand: Drei Gruppen zuischen Überlebenskampf und politischer Aktion 1939-1945, ed. Werner Vathke and Wilfried Lohken (Berlin, 1993), 159-205.

61. For some years now a research project about the rescue of German Jews during the NS period is under way at the Zentrum für Antisemitismusforschung (Technische Universität Berlin).

62. Klemperer, Tagebücher 1942-1945,335-36, entry of 27 February 1943.

63. See discussion in Hilberg, 2:437-49; Uwe-Dietrich Adam, Judenpolitik im Dritten Reich (Düsseldorf, 1972), 322-26; and Adler, Mensch, 287-88.

64. Wolf Gruner, "Die NS-Judenverfolgung und die Kommunen: Zur wechselseitigen Dynamisierung von zentraler und lokaler Politik 1933-1941," Vierteliahrshefte fir Zitgeschichte 48 , no. $1(2000)$ : $75-126$, here 75 . 
addressing the forced dissolution of these marriages ${ }^{65}$ As in the case of the politics toward Mischlinge, one wished to avoid unrest during wartime among the "German-born" population, and, after several sessions, the question of forced dissolutions of marriages was eventually tabled at the end of $1942,{ }^{66}$ thus removing the precondition, still considered necessary by the NS leadership, for the deportation of those Jews in mixed marriages.

At the beginning of 1943 , a total of 16,760 people lived in mixed marriages in Germany proper, half of them in Berlin, which is around 6,000 Jews in "privileged mixed marriages" and ca. 2,800 in "nonprivileged mixed marriages." ${ }^{67}$ All documents on hand at this point in time lead to the fact that the deportation of these people was not the aim of the factory action. The RSHA guidelines of 20 February, operational for the last great deportation wave, provided explicitly that the following groups of Jews were to be excluded from the transports: Jews in mixed marriages, those Jewish spouses who were freed from having to wear the yellow star even though their marriages had been terminated, as well as Geltungsiuden, that is Mischlinge (of mixed blood) who, according to NS racial categories, were considered to be Jews. ${ }^{68}$ As shown above, for the factory action the RSHA had specific orders: "Insofar as there are no reasons to justify the arrest of Jewish spouses living in a mixed marriage, they are to be released to their home. In no case must they again be employed in this or any other firm. Futher instructions regarding their further utilization will follow." ${ }^{69}$ Thus, they were to be removed from industry and their "use," that is forced labor, was to be reorganized. They were, however, not to be deported. Consistent with the above, Victor Klemperer received a letter from Lewinsky already on 28 February 1943 telling him not to worry, "The present action is not aimed at mixed marriages."

65. Protocol of the conference in Kurt Pätzold and Erika Schwarz, Tagesordnung: Judenmord: Die Wannseekonferenz am 20. Januar 1942: Eine Dokumentation zur Organisation der "Endlosung" (Berlin, 1992), 109-11. Longerich stresses that Heydrichs's statements concerned longterm projects, not actual practice; Peter Longerich, Die Wannsee-Konferenz vom 20. January 1942: Planung und Beginn des Genuzids an den europäischen Juden (Berlin, 1998), 46. Stoltzfus und Schröder, by contrast, take the references to "mixed marriages" as final decisions; Stoltzfus, Aufstand, 235-36; Schröder, Gegnerinnen, 48.

66. See Hilberg, Vernichtung, 2:440-49.

67. LBI/A New York, Microfilms: Wiener Library, 500 series, no. 526: Inspector for Statistics at RFSS as of 1 January 1943 „Die Endlösung der europäischen Judenfrage“ (1. Korherr-Bericht), 6. The "mixed marriage" numbers of Berlin are from beginning of 1942. Since they were not deported, the numbers should have remained the same; BA Berlin, R 8150, Film 52407-23, fols. 152: Number of Jews 31 January 1942 (RV-Statistik).

68. BA Berlin, Zeitgeschichtliche Sammlung 138, unfol; partly printed in Adler, Mensch, $199-200)$

69. BLHA Potsdam, Pr. Br. Rep. 41 Grossräschen, Nr. 272, fols. 84-85: order Gestapo Frankfurt/Oder of 24 February 1943.

70. Klemperer, Tagehiucher 1942-1945, 337, entry of 28 February 1943. 
At first sight, the Berlin situation presented a different picture. On 2 March 1943, Cardinal Adolf Bertram, the chairman of the German Conference of Bishops, received a letter in Breslau giving a detailed report about the events in the German capital:

In Berlin, on Saturday, 27 February, the evacuation began to an extent and with a severity hitherto not seen in Berlin. Within two days, ca. eight thousand non-Aryans were arrested without regard to the fact that they had long been baptized - often for decades, but above all this time without regard to whether or not they lived in mixed marriages, thus even Christian mixed marriages were forcibly dissolved. All efforts of the Aryan spouses and the half-Aryan children to free the non-Aryan spouse or parent prove futile [...]. As far as we could ascertain (in strictest confidence) those arrested from mixed marriages, as of Monday night, are not yet included in the evacuation transports.

Immediately, still on the same day, Cardinal Bertram urged the Berlin bishop Wienken, "to register, in the name of the entire episcopacy, an oral protest" with several ministries, the Reich chancellery, and the Reichssicherheitshauptamt."

What had happened? Did the RSHA orders not apply to the capital? Was this a special action to deport the Jews living in mixed marriages??2 Since neither the church nor the relatives of the victims knew the true plans of the persecutors, they assumed that deportation was imminent. The Berlin Gestapo, however, was always careful to separate those Geltungsjuden and Jews living in mixed marriages who were arrested during the raid, after they arrived at the various collection points, from those to be deported. At the barracks Rathenowstrasse every one "had to step up to a long table and was most meticulously checked by a Gestapo officer. ${ }^{73}$ At the Hermann-Göring barracks those separated in this way were officially informed, Otto Fried remembers, "that we would be exempted from the evacuation." $7+$ Some were released immediately or during

71. Letter of Margarete Sommer (Hilfswerk für jüdische Katholiken beim Bischöflichen Ordinariat Berlin), (ca. 2 March 1943), in Akten deutscher Bischöfe, vol. VI, 1943-1945, Dok. 817, 19-21. Telegram of 2 March 1943, in ibid., 21, n. 3. Bertram himself sent parallel written requests to the same NS institutions; ibid., Dok. 818, 21-23: letter of 2 March 1943.

72. See the main thesis of Stoltzfus, Resistance of the Heart.

73. AS LG Berlin, Js 9/65, ZH 75, fols. 6: witness interrogation of Gerda Kühne1, 30 September 1966. See Henschel, Arbeit, 47-48. For specific camps see AS LG Berlin, Js 9/65, ZH 110, fols. 11-12: interrogation Curt Radlauer, 10 November 1966; ibid., 3 P Ks 1/71, vol. XII, fols. 89-90: witness interrogation Julius Coper of 1 November 1965; ibid, fols. 80: interrogation Kurt Block, 28 October 1965; ibid., vol. XVIII, fols. 37: interrogation Rudolf Schwersensky, 15 April 1966; report Löwenstein in Schröder, Gegnerinnen, 174; report in Diana Schulle, "Gebt unsere Männer frei!," in Juden in Berlin 1938-1945, ed. Beate Meyer and Hermann Simon. Catalog to the exhibition of the same title, Stiftung ,Neue Synagoge Berlin - Centrum Judaicum“ Mai to August $200 \%$ (Berlin. 2000), 163-64.

74. AS LG Berlin, 3 P Ks 1/71, vol. XVIII, fols. 21: witness interrogation Otto Fried, 13 April 1966. Similar description in Stoltzfus, Aufstand, 295. See report Erika Lewin in Schröder, Gegnerinnent, 116-17 
the following days. ${ }^{75}$ Nevertheless, most of those sorted out at the collection points were brought to an administration building of the Jewish Community. A survivor remembers that, "After they had a group collected, they said that we could go home. But we were loaded unto trucks. Then we came to the Rosenstrasse where the SS told us that we were there only for investigation [ . . . ${ }^{176}$

On the basis of survivor reports, it was estimated until now that the Gestapo had eventually interned between fifteen hundred to two thousand people in the Rosenstrasse. For the first time, these numbers can be confirmed by a contemporary source located by the Hamburg historian Beate Meyer. In an entry dated 7 March 1943, the Reichsvereinigung puts the number of inmates at ca. two thousand. ${ }^{77}$ Thus, by no means all Berlin Jews from mixed marriages, who, after all numbered above eight thousand, had been arrested, but apparently mainly those working as forced laborers in the armaments industry. This fact, as well as the obvious separation at the collection points, contradicts the finding that in Berlin a special action had been carried out against all Jewish spouses in mixed marriages. It speaks as well against any "accidental" internment. The following source, until now barely considered, also clearly rebuts this. On 4 March 1943, Bishop Wienken related to Cardinal Bertram a personal discussion (Aussprache) with Adolf Eichmann "who just now gave the following assurance: 1 . The non-Aryan Catholics in racially mixed marriages will not be included in the 'Abwanderungsaktion' (emigration action). [. . .] 3. The non-Aryan Catholics of racially mixed marriages who were removed from their places of work and at times also from their homes at the end of last week in Berlin will be released $[\ldots] .,{ }^{\prime 78}$

If their deportation was not planned, what then was the reason for the internment of so many people in the Rosenstrasse? In any case, open questions concerning the classification as Geltungsjuden and Jews in mixed marriages were to be resolved by the Gestapo. As a note in the files of the Reichsvereinigung shows, this had been ordered by the RSHA. After the war, Hildegard Henschel reported that the examination of those "Aryan-related" in the Rosenstrasse was

75. Copy of a discharge paper from camp „Clou“ dated 28 February 1943, in Rivka Elkin, Das juidische Krankenhaus in Berlin zurischen 1938 und 1945 (Berlin, 1993), 50. See the diary of Becker in "Ich fürchte die Menschen mehr als die Bomben," Aus den Tagebuichern von drei Berliner Frauen 1938-1946, ed. Angela Martin and Claudia Schoppmann (Berlin, 1996), 41-42; report Makower in Ball-Kaduri (Berlin), 211-12; report Kirchner in Herzberg, Überleben, 370-71; report Rita Kuhn in Alison Owings, Frauen: German Women Recall the Third Reich, 2d ed. (New Brunswick, N.J., 1995), 459-60.

76. Conversation with K. A. in Zehn Brider waren wir gewesen, 405-6. After a few days, the Gestapo transferred approximately 150-200 "protected" from the camp in the Grosse Hamburger Strasse to the Rosenstrasse; report Alfred Wagner in Schulle, Männer, 163.

77. See Beate Meyer, "Die Inhaftierung der 'jüdisch Versippten' in der Berliner Rosenstrasse im Spiegel staatsanwaltlicher Zeugenvernehmungen in der DDR," in Jahrbuch für Antisemitismusforschung 11 (Berlin, 2002), 186.

78. Akten deutscher Bischöfe, vol. VI, Dok. 820, 25. 
conducted in a thorough manner in accordance with the relevant guidelines of the Gestapo. ${ }^{79}$ During this process sporadic discharges began on 1 March. For example, the father of Anneliese Bach was let go "after a few days" after he had presented "the papers proving a mixed marriage." "su

Yet, the examination of people's racial status could hardly have been the sole reason for the internment. Actually, not all Jewish partners in mixed marriages were brought to the Rosenstrasse. Moreover, most of the people brought there were men. The main reason for their days-long incarceration has so far been overlooked: as the following documents attest, the Gestapo wished to select new personnel for the Jewish organizations. Following the completion of the last wave of deportations, the RSHA planned to allow only a reduced administration to care for the few remaining Jews. Jews from mixed marriages were now to replace those Jews who, as workers at Jewish organizations, had so far enjoyed the status of "protected Volljuden," and who would now quickly be deported. The fact that predominantly men both from privileged and nonprivileged marriages were interned had to do with their future administrative assignments at the time mostly performed by men - and not with the fact that only Jews from nonprivileged marriages were kept in the Rosenstrasse. ${ }^{x 1}$

In places other than Berlin, the old personnel of Jewish institutions could easily be replaced by a few dozen people from the circle of Jews living in mixed marriages. In Hamburg, for instance, the exchange was managed by the local labor office. ${ }^{82}$ In the capital, however, the process took on a much greater dimension, because this was the seat of the Reichsvereinigung and of the largest Jewish cultural community in Germany, therefore, hundreds of people had to be hired. Although there had been discharges and deportations since 1941, at the end of January 1943 the Jewish Community still employed 815 workers, the Reichsvereinigung 174 , together almost 1,000 people, after whose deportation quite a few of them had to be replaced. ${ }^{83}$ As a result of the great raid and the following deportation, for example, accurate data on the Jewish population were

79. BA Berlin, R 8150, no. 50, fols. 417 u. RS: RV-Notiz Nr. 243 regarding the meeting at RSHA on 9 March 1943. Henschel, Arbeit, 50.

80. CJA Berlin, 4.1, no. 56, unfol.: letter of 2 August 1946. See reports in Stoltzfus, Aufstand, 306; report in Schröder, Gegnerinnen, 118-22.

81. Stoltzfus asserts that mainly Jews from nonprotected mixed marriages were interned and that was the reason for so few women being in the camps; Stoltzfus, Aufstand, 401-2; similarly Schröder, Gegnerinnen, 48. Yet, even if one accepted this questionable assumption, the number of women should have been much higher. It is of course possible that the number of women in "mixed marriages" who worked in industry was lower than that of men, because they were more often categorized as "privileged," but there is no way that the extremely uneven share of the interned of a little more than one hundred women to far more than a thousand men could be correct.

82. BA Berlin, R 8150, no. 51, fols. 233: Jïdischer Religionsverband Hamburg (Plaut) to RV on 12 March 1943.

83. Ibid., fols. 4: Note concerning the workforce JKV Berlin on 31 January 1943. Also CJA Berlin, Diverses JKV Berlin, unfol.: Reorganisationsplan für RV und JKV Berlin of 31 January 1943. I am grateful to Thomas Jersch (Berlin) for pointing out the latter source. To the discharges and deportations, see Gruner, Reichshauptstadt, 246-51. 
no longer available and the Gestapo would have required weeks to seek replacements. The gathering and internment of two thousand people at the Rosenstrasse presented the best opportunity quickly to recruit a few hundred persons for work in Jewish offices. At the time the Gestapo did not disclose any information about either the exchange or the imminent deportation of the old employees. They had learned from their experience of October 1942 when, after the announcement that about five hundred employees of the Berlin Jewish Community would be deported, twenty of them had fled. ${ }^{8+}$

During the first days in the Rosenstrasse the Gestapo chose several of the internees for smaller specific tasks - for instance ten men were assigned as porters for the still ongoing arrests - before it eventually chose larger numbers of future personnel for work in Jewish organizations by canvassing the building. ${ }^{85}$ Beginning on $5 \mathrm{March}$, the discharges from the Rosenstrasse increased. ${ }^{86}$ The big wave of releases began on 6 March. The deportation of almost seven thousand Berliners within only six days had apparently required such an enormous organizational effort that the Gestapo could turn their attention to the new tasks only after the last transport had left for Auschwitz on 6 March. Even then the selection of replacement personnel still dragged on for several days. The courtyard roll calls reported by some survivors were apparently part of the search. ${ }^{87}$ Curt Radlauer later remembered, "While still in the Rosenstrasse on the occasion of a roll call in the courtyard, I was asked by the Gestapo official Prokop about my profession and whether I know something about the administration of real estate and mortgage law. When I answered in the affirmative, he ordered me to keep myself available for such work at the Jewish Community in the Oranienburger Strasse. ${ }^{88}$

Until the 8th of March many internees were gradually released, at first mainly those who were not to be selected for any job at the Jewish institutions. They were ordered immediately to report for forced labor to the Sonderdienststelle for Jews at the Berlin labor office before they were given food ration cards. ${ }^{89}$ All of

84. Gruner, Reichshatutstadt, 246-51.

85. AS LG Berlin, 3 P Ks 1/71, vol. XII, fols. 82-83: Witness interrogation Kurt Block, 28 October 1965; see also ibid., vol. XXXIII, fols. 187: witness interrogation Erich Munter of 26 October 1967; report in Hartung von Doetinchem, Zerstöte Fortschritte, 200-1.

86. See copy of discharge paper of 5 March 1943 from collection point Rosenstrasse; Schröder, Gegnerinnen, 96f. For discharges of 5 March 1943 see e.g., CJA Berlin, 4.1., no. 105 and 173, unfol.

87. AS LG Berlin, 3 P Ks 1/71, vol. XII, fols. 91: witness interrogation Julius Coper, 1 November 1965; also report Lilo Merten in Schröder, Gegnerinnen, 260.

88. AS LG Berlin, Js 9/65, ZH 110, fols. 11-12: witness interrogation Curt Radlauer, 10 November 1966. Radlauer then worked at the Rechts- und Abwicklungsstelle; CJA Berlin, Diverses JKV Berlin, unfol.: Stellenplan JKV Berlin of 1 April 1943.

89. See copies of two discharge papers of 7 March 1943 in Schröder, Gegnerinnen, 215-16. See note „Keine Ausgabe von Lebensmittelkarten“ on discharge paper of 5 March 1943, copy in Regina Girod, Reiner Lidschun, and Otto Pfeiffer, "Nachbarn: Juden in Friedrichshain," ed. Kulturring in Berlin e.V. (Berlin, 2000), 66. For more discharge dates of 6 to 8 March 1943, see CJH Berlin, 4.1. 
those released were in desperate physical, psychological, and hygienic shape. They had passed more than a week in overcrowded rooms without being able to wash or to get sufficient sleep. ${ }^{\text {\%) }}$

Finally, on March 9, those selected to work in the Jewish offices were transferred from the Rosenstrasse to the main building of the Jewish Community. More detailed information about the procedure is contained in the files of the Reichsvereinigung. Kurt Levy personally rendered his report on the afternoon of 9 March at the RSHA (Amt IV B 4 A) to Amtmann Fritz Woehrn about the exchange: "On 6 March 1943 at the collection point Rosenstrasse, 302 exchange personnel were selected, some of whom, however, did not meet the requirements of the RV. The camp leadership later offered additional replacement workers and on the morning of 9 March 1943, 320 people were sent from the Rosenstrasse to Oranienburger Strasse 29 in order to be examined individually as to their suitability for the respective jobs." According to Levy, by 1 P.M. 190 replacements had been selected for positions, however, by that time not all people had been examined. Vacancies were still unfilled for the building department of the Jewish Community, for caregivers in the health department, stenographers, as well as workers for Amt VII of the RSHA. Amtmann Woehrn (RSHA), according to Levy's report, ordered the latter to keep the number replaced to 225 , and to limit those strictly to "Jews from mixed marriages or divorced mixed marriages who had been exempted from wearing the Jewish star, and further to Geltungsjuden who reside with an Aryan parent (when not married to a Jew).".11

A comparison of the available personnel rosters of the Berlin Jewish Community of 31 January 1943 and 1 April 1943 allows a more precise view into this organization: for example, after the factory action eight men and one woman living in mixed marriages as well as a Geltungsjüdin were newly hired for the Dues and Fees Office of the Jewish Community. The department Gesamtarchiv now had seven men living in mixed marriages, only one of whom had previously worked there. ${ }^{92}$ New personnel were chosen from the circle of the interned for both the Reichsvereinigung and for the Jewish hospital. ${ }^{93}$ The RSHA and the Gestapo itself needed dozens of men: twenty Jews from mixed marriages were selected as additional sorters for the collection point Grosse-

90. Stoltzfus, Aufstand, 335.

91. BA Berlin, R 8150, Nr. 50, fols. 417: RV-Notation no. 243 concerning meeting at RSHA on 9 March 1943.

92. Figured according to Stellenplan JKV Berlin of 1 April 1943 and Mitarbeiterstand JKV Berlin (list of names) of 31 January 1943; CJA Berlin, Diverses JKV Berlin, unfol. I wish to thank Thomas Jersch (Berlin) for this source.

93. Ball-Kaduri (Berlin), 226; AS LG Berlin, Bovensiepen-Prozess, vol. XXX, fols. 94: witness interrogation Walter Freund of 22 May 1967; CJA Berlin, 4.1, no. 150, unfol.: Letter Eva Bileski of 9 October 1945; Hartung von Doetinchem, Zerstorte Fortschritte, 198-200. See CJA Berlin, Diverses JKV Berlin, unfol.: RV-Stellenplan of 11 Nov. 1943. 
Hamburger-Strasse, and twenty-seven for the transport- and pick-up group that had to accompany the Gestapo during their sweeps. For building- and library work the RSHA (Amt VII) recruited twenty-four Jews from mixed marriages at the Rosenstrasse collection point. ${ }^{94}$ Starting with the factory action, 115 men and four women from mixed marriages were thus newly employed by the Jewish Community, also sixteen Geltunsgjüdinnen and twelve Geltungsjuden. Adding fifty new employees at the Jewish hospital who appear on a list of November 1943 , there were approximately two hundred new replacement workers. ${ }^{95}$

During the following days, those recruited, mainly all men, were given employee passes. They were threatened by the RSHA that, should they not work out, they would be detailed by the labor office Arbeitsamt for further use as forced laborers. ${ }^{96}$ Hildegard Henschel, then working at the Jewish Community offices, reported on the new workers' first day of work: "Worn down by the recent events [ . . ] the task was to fill all necessary posts with Jews who had not been evacuated and had Aryan relatives. Prior to this time, only a few of this group had worked in Jewish organizations. They had to become familiar with their jobs, so that, even after the removal of all Volljuden, the machinery would continue to function." ${ }^{97}$

As early as March 9, that is, on the very day when those selected were sent to the Jewish Community, the mass arrests of the "old" employees of the Jewish Community and the Reichsvereinigung began. A day later, half of the "old" hospital personnel were taken away. During the following days, a total of two thousand persons were deported by the Gestapo, among them apparently 450 former employees of the Community and their relatives. One transport left on 12 March for Auschwitz, another on 17 March for Theresienstadt. ${ }^{98}$ Only after the departure of these two transports did Goebbels report to the Führer that, "most of the Jews have been evacuated from Berlin."

94. See n. 94. See also BA Berlin, R 8150, no. 50, fols. 430: notation (Moritz Henschel) concerning discussion at Stapoleitstelle Berlin (Stock, Dobberke) on 18 March 1943.

95. Forty-seven men and two women from mixed marriages as well as two Geltungsjiidirnen kept their jobs. See n. 94 and RV-Stellenplan of 11 November 1943, ibid.

96. Copies of some of these passes in Jidische Geschichte in Berlin: Bilder und Dokumente, 323. BA Berlin. R 8150, no, 50, fols. 417RS: RV-file notation no. 243 concerning discussion at RSHA on 9 March 1943.

97. Henschel, Arbeit, 50.

98. Ibid., also Elkin, Krankenhaus, 39-40; Hartung von Doetinchem, Zerstörte Fortschritte, 191-92. In January 1943 the Conmunity had over eight hundred workers, at the end of March only 450 remained (plus ca. 100 at the hospital). Since two hundred of them were newly-hired Jews from mixed marriages, 450 people were missing, all so-called Volliuden; see n. 94 and RV-Stellenplan of 11 November 1943, ibid. For the transports see Gedenkbuch Berlins, 1420-22; see Gruner, Judenverfolyung in Berlin, 99-101.

99. Tagebücher won Joseph Goebbels, part 2, 7:595, entry from 20 March 1942. 


\section{The Protest at the Rosenstrasse}

On 11 March 1942 Goebbels noted in his diary: "The evacuation of the Jews from Berlin caused some unpleasantnesses after all. Unfortunately, Jews, both men and women from privileged marriages were initially also arrested, which led to great anxiety and confusion." ${ }^{100}$ As a result of uncertainty over the fate of their relatives interned at the Rosenstrasse, many people, mainly non-Jewish family members and predominantly women, gathered in front of the building soon after the factory action.

The picture of the events one receives from interviews, memoirs, and trial testimony is a diffuse one. In some of these accounts - often given decades after the events - the postwar story of the "Aufstand der Frauen" had left distinct traces. ${ }^{111}$ To this date, the actual circumstances, the number of those taking part, and the form of the protest have not been definitively established. Some contemporary witnesses estimate that on different days about 150 people were at the Rosenstrasse. ${ }^{112}$ According to the diary of Andreas-Friedrich, however, there were 6,000, according to the estimate of Schröder, 2,000 people were in the street at one time. ${ }^{103}$ Stoltzfus maintains that up to 600 people had participated together in the form of a "flowing procession of demonstrators (Demonstrationszug)" and, at another place, that the street was "black" with people, that at the end of the days-long protests, altogether 6,000 people had taken part. ${ }^{1 / 4}$ Joch heim, by contrast, assumes that altogether 1,000 protested. He points out, however that, while these people were standing in front of the building or were walking around, no demonstration by today's definition took place. ${ }^{115}$

The systematic reading of postwar reports available today shows that this latter assessment is supported by the recollections of a considerable number of women participants. ${ }^{106}$ Ursula Braun reports: "We didn't do anything at all in the Rosenstrasse. I walked up and down. One talked [ . . ]. To be sure, one also

100. Ibid., part 2, 7:528, entry from 11 March 1942.

101. See, for example, Gad Beck, who as former inmate refers to the traditional "facts," including the mounted and then withdrawn machine guns of the SS"; Und Gad ging zu David, 101. See also the testimony in Bovensiepen-Prozess: LAB, Rep. 057-01, no. R 34/34, unfol.: witness interrogation Walter Freund of 22 May 1967, 4; AS LG Berlin, 3 P Ks 1/71, vol. VII, fols. 4: witness interrogation Curt Naumann, 14 July 1965; ibid., vol. V, fols. 43: witness interrogation Harry Schnapp (undat.).

102. Report Charlotte Israel in Grinewald-Rampe, 147; report Gad Beck in Schröder, Gegnerimen, 144

103. Andreas-Friedrich, Der Schattenmann, 103-4; Schröder, Gegnerinmen, 29.

104. Stoltzfus, Aufstand, 12, 295, 309; idem, Protest, 218.

105. Jochheim, Frauenprotest (1993), 137

106. Reports Erika Lewin, Miriam Rosenberg and Lilo Merten; ibid., 108, 175, and 235; report Ruth Gross, in Aus Nachbarn ururden Juden: Ausgrenzung und Selbstbehauptung 1933-1942 (catalog to the exhibition of the same title), ed. Hazel Rosenstrauch (Berlin, 1988), 129; reports Frau Weigert and Hilda Elkuss bei Stoltzfus, Aufstand, 302, 311; AS LG Berlin, Js 9/65, ZH 110, fols. 13: Zwischenvermerk Anna Radlauer in witness interrogation Curt Radlauer of 10 November 1966. 
kept an eye on the gate in order to see whether anything was happening. But otherwise we were unable to do anything but mill around or walk up and down. And at all times there were people there. At times only a few, at times more, but at all times there was a noticeable gathering of people. That's what was amazing." 1117 Some returned daily, others rotated with family members. Some "merely" wanted to deliver food, or wished to gather information about their family members. Men were also waiting there, some even in uniform. ${ }^{108}$

The Berlin Gestapo was in charge inside the building. The ordinary police (Schutzpolizei) guarded the outside. According to a survivor report, at the beginning there was an SS guard present, who was withdrawn after two days as a result of the protest. ${ }^{11,9}$ Another survivor remembered that a car with SS men drove through the street and threatened the crowd. ${ }^{111}$ A further report had it that on 4 March the SS had at first mounted machine guns, which, after the protest, were again taken down. ${ }^{111}$ The only thing certain seems (because here the testimony of several contemporary witnesses agrees) that on several occasions the police disbursed the gathering. Ursula Braun reports: "The guards came around again and again and ordered: 'Disburse! Go to the other side of the street." "12 In addition, other survivors said that some moved away temporarily because of the police, that others hid in doorways or in the small adjacent streets and came back after a little while. ${ }^{1{ }^{13}}$ For a few dozen people, such behavior would have been possible without problems in the small street of about 150 meters (less than today), but not for hundreds or even thousands of protesters.

Although it becomes clear that one cannot speak of a large demonstration, or a powerful protest, in each case it took great personal courage to take part in the gathering in front of the building in the Rosenstrasse and to persevere there repeatedly for hours in the face of official threats. This political action ended with the release of the interned. Jochheim and Stoltzfus assume that within the NS leadership the view prevailed that the protest could not be ended by force but only through the release of the inmates. ${ }^{11+}$ Why then should the NS

107. Report Ursula Braun in Schröder, Gegnerinnen, 82.

108. AS LG Berlin, Js 9/65, ZH 110, fols. 13: Zuischenvermerk Anna Radlauer in witness interrogation Curt Radlauer, 10 November 1966; ibid., fols. 14: witness interrogation Curt Radlauer of 10 November 1966; also report Löwenstein in Schröder, Gegnerinnen, 211; report Hans Reichow in Horst Helas, Juden in Berlin-Mitte: Biografien, Orte, Begegnungen (Berlin, 2000), 210.

109. Hans-Oskar Löwenstein concerning the testimony of his mother; Schröder, Gegnerinnen, 213.

110. Elsa Holzer bei Stoltzfus, Aufstand, 320-21. In her report in Schröder, she does not mention it. Schroder, Gegnerimen, 267-86.

111. According to Hans Grossmann in Jochheim, Frauenprotest (1993), 131-32.

112. Schröder, Gegnerimen, 90-91.

113. Report Ruth Gross, in Aus Nachbarn ururden Juden, 129-30; idem, report as well as reports Ernst Bukowzer and Frau Weigert in Stoltzfus, Auffstand, 299, 307-8.

114. Jochheim, Fratenprotest (1993), 136-37; Stoltzfus, Aufstand, 347. 
leadership have waited so long and tolerated for days the public protest of a large gathering of people? It may well be more plausible that far fewer people than previously estimated had gathered and the form of their protest had been less provocative than has been described in the scholarly literature. Furthermore, it was not the unique engagement of many women and men that brought about the release of their relatives, since no deportation had been planned.

In the absence of documentary evidence, the accepted thesis of an alleged halt to deportations on 6 March is based solely on a diary entry by Goebbels, who recorded on that day "unfortunate scenes" "where the population had gathered in significant numbers and had even somehow sided with the Jews." Goebbels wrote that he had ordered the SD "not to continue the evacuation of the Jews at such a critical moment," and that he had criticized those officials who, without thinking, "clung to a written word." This entry, however, can only refer to the general deportation for which alone written orders existed. The much-cited notation of $6 \mathrm{March}$, therefore, must be attributed to the selfstylization of the propaganda minister in his diary that he kept for posterity. He may have spoken with Himmler or the RSHA chief Ernst Kaltenbrunner, but he could hardly have given orders to the SD, which, after all, had no direct involvement in the Gestapo action. ${ }^{115}$

In order to corroborate the thesis of the break-off of a planned deportation due to the protest, the case of twenty-five men from the Rosenstrasse who were taken to Auschwitz on 6 March with the fifth transport of the factory action and surprisingly came back is cited in the literature. ${ }^{116}$ In fundamental contrast to the other six hundred people deported on that day, they were brought to Auschwitz under "protective custody." This previously ignored circumstance alone is responsible for their return after a few weeks. Beginning in the autumn of 1942, assignment into protective custody or to a KZ for Jews (Volljwden) indeed also meant a transport to Auschwitz. The twenty-five Berlin men, however, still counted as "protected" Jews from mixed marriages, and that is why, after fourteen days of forced labor at Auchwitz-Monowitz, they were returned to Berlin and taken to the Arbeitserziehungslager Grossbeeren. ${ }^{17}$ As a further proof of the intention to deport those seized, arrests of the Jews from mixed marriages in Frankfurt am Main are cited. ${ }^{118}$ The latter, however, cannot be equated with the deportation; here the cause for the arrests, as in Hamburg,

115. Tagebuicher von Joseph Goebbels, part 2, 7:487: entry of 6 March 1943. See Jochheim, Frauenprotest (1993), 133; Stoltzfus, Protest, 227-28. Rainer Decker makes the same objection to this assumption in his Online-review of Stoltzfus's book (http://hsozkult.geschichte-hu-berlin.de/ rezensio/buecher $/ 2000 /$ dera0500.htm).

116. Jochheim, Fratuenprotest (1993), 170); Stoltzfus, Aufstand, 323-25, 391).

117. To the classification of the 25 Männer as "people in protective custody" (Schutzhafflinge) see cable of 8 March 1943 to the WVHA, in Topographie des Terrors, 119; Czech, Kalendarium, 434.

118. Stoltzfus, Aufstand, 36. He states that the RSHA prepared for their transport, but uses as the only proof the findings of a postwar trial; ibid., 277. 
Krefeld, Offenbach, Mainz, Wiesbaden, and Darmstadt was actual or alleged offenses against NS laws. ${ }^{119}$ As becomes clear from the above-cited order of the Gestapo Frankfurt/Oder, the RSHA, in individual cases and for reasons of repression, had explicitly allowed the imposition of protective custody for members of this group during the factory action.

While in the spring of 1943 the NS leadership had no concrete intention to deport Jews from mixed marriages, at a minimum, after deporting most of the remaining Jews, it wished to intensify the persecution of the "protected Jews" within the Reich. Instead of working in industry as they had done until now, Jews living in mixed marriages were now forced to perform hard manual labor solely. In Berlin, as well as in other cities, the labor office compelled male and female Jews, many from the Rosenstrasse, to work for the Reichsbahn, in garbage removal, and for firms clearing debris after bombings. ${ }^{121}$ At the same time, they were crowded together into "Judenhäuser" in Hamburg, Halle/Saale, Bremen, and Frankfurt am Main. Moreover, the divorce laws considered necessary for deportation were discussed in the NS leadership, once again without result. A year after the factory action on orders from Himmler, the Gestapo deported those Jewish men and women to Theresienstadt whose mixed marriages had ended either through divorce or death. Finally, on 15 January 1945 the RSHA ordered that, even in the absence of forced divorce, all Jews living in mixed marriages were to be deported. Beginning on 12 February over a dozen transports with more than 1,600 people from German cities were sent to the KZ Theresienstadt. ${ }^{121}$

\section{Conclusions}

The great raid of the end of February-beginning of March 1943 presented on the whole the third largest anti-Jewish raid within Germany proper, next to the expulsion of Polish Jews at the end of October 1938 and the arrest on the occasion of the November pogrom (Kristallnacht) of 1938. On the day of the great Berlin raid, in the capital of the Third Reich, the Gestapo, with the help of the SS, brutally pulled thousands of people out of probably more than a hundred firms and crammed them into collection camps. The raid, named by survivors the "factory action," was not limited to Berlin. Throughout the entire Altreich (old Reich), Jews and Jewesses were removed from their work places,

119. See Kingreen, Frankfurt, 383; Meyer, ,Jüdische Mischlinge," 58-59; Johnson, Terror, 460-63.

120. Gruner, Arbeitseinsatz, 322-26. See CJA Berlin, 4.1, no. 149, 284, 1495, 1527, 1529 , 1631. unfol.

121. Gestapo order, 18 December 1943 cited in Stoltzfus, Protest. 230. On 10 January 1944, a transport with 354 persons left Berlin, Gedenkbuch Berlins, 1433. See the cases: CJA Berlin, 4.1, no. 257, 379, 261, 179. Gruner, Arbeitseinsatz, 328-29; Institut Theresienstädter Initiative, ed., Theresienstädter Gedenkbuch: Die Opfer der Judentransporte aus Deutschland nach Theresienstadt 1942-1945, ed. (Prague, 200()), 89. 
arrested on the streets and in their homes, and then interned at collection points, for example synagogues (no longer used for their original purposes), military barracks, rural guest houses, slaughter houses, as well as forced labor camps, prior to deportation. In the first week of March the Gestapo deported 11,000 people to Auschwitz.

In this huge raid the Gestapo at the beginning of March at first took mainly (but not exclusively as is being maintained) forced female and male laborers. ${ }^{122}$ The action represented the start of the last great wave of deportations in Germany, in which all so-called Volljuden who were not considered as protected in mixed marriages were to be evacuated. Hence, family members of forced laborers, and, until the middle of March, hundreds of employees of Jewish institutions and their relatives, were also taken away. The number of deportees from the Reich, altogether 12,496 men, women, and children who were deported during March 1943 was actually one of the highest monthly transportations since deportations began in Germany. ${ }^{123}$

Contrary to the current view, sources hitherto ignored prove that in February 1943 the RSHA in no way planned to deport Jews living in mixed marriages. The aims of the factory action directed by the RSHA were merely to remove this group from industrial work in order to use them in the future exclusively in hard manual labor. The internment of approximately a fourth of Berlin Jews living in mixed marriages also was apparently initiated by the RSHA. The victims, predominantly men and some women, who had hitherto performed forced labor in industry, were segregated from the others at the collection points and then taken to a separate camp in the Rosenstrasse. One reason for the internment of these two thousand people might well have been to examine their racial status, but above all else, the internment took place - and this has been completely overlooked until now - in order to recruit from their circle several hundred new workers for the Jewish institutions of Berlin. More than two hundred Jews from mixed marriages eventually replaced about 450 "fully Jewish" employees of the Reichsvereinigung, the Jewish Community and its hospital who, with their families, were then deported up to the middle of March. As the above shows, the deportation of Jews from mixed marriages was neither planned to start in Berlin during these days, nor was Goebbels responsible for their internment or, what is more important, for their release from the Rosenstrasse, as has been asserted. ${ }^{124}$

122. See these theses in Enzyklopadie des Holocaust: Die Verfolgung und Ermordung der europäischen Juden, ed. Israel Gutman, German edition by Eberhard Jäckel et al. (Munich, 1995), 1:342.

123. BA Berlin, R 8150, no. 69, fols. 57: RV-Statistik für März 1943; see Gruner, Reichshauptstadt, 253.

124. The thesis concerning the decisive role of Goebbels in Stoltzfus, Aufstand, 13, 346. Stoltzfus contradicts himself at another place when he asserts that the internment had been a local action of lower ranking Gestapo officials; Stoltzfus, Aufstand, 353. After Stoltzfus in Johnson, Terror, 455. 
In contrast to the current view, no deportation plan was scuttled as a result of the Rosenstrasse protest of the relatives. ${ }^{125}$ Already before 6 March, the date on which some scholars have assumed the deportations of Jews in mixed marriages had been stopped, and even days later, people were released from the camp. The conventional wisdom about the protest has to be revised, although further in-depth research is still needed. Due to the uncertainty of the fate of their relatives interned at the Rosenstrasse, many people had spontaneously gathered and remained in front of the building for hours. Many returned day after day. Some brought food, others waited for information. The police apparently frequently disbursed them. Yet, there were apparently far fewer people than has until now been assumed. This correction of the historical events, however, does not by an iota reduce the importance of the action of the people in the Rosenstrasse, because they acted in the absence of any knowledge of the goals of the internment action, but out of worry for their relatives and fear of their imminent deportation.

The protest in the Rosenstrasse was not the first event that divided the NS leadership over the question of how they would handle the Jews from mixed marriages, as Stoltzfus assumes. Their future had been discussed as early as 1941 . Moreover, the protest of 1943 did not lead to paralyzing battles among the Reich's centers of power or to controversies within the NS leadership. One may therefore not deduce from the sources that such "demonstrations" could have altered the deportation plans of the NS leadership or delayed their realization at this late date. As has been shown, the protest neither prevented the intensification of the policies of persecution toward Jews in mixed marriages in the Reich, nor, as Stoltzfus would have it, later deportation. ${ }^{126}$

The story of the "successful" protest in the Rosenstrasse has meanwhile been inscribed into the collective memory of the Germans as the symbol for individual resistance against the NS dictatorship. Shortly after the end of the war, the assurance that during the NS period there had been protests against the persecution of the Jews obviously served the self-understanding of the new German civic entity (Gemeinwesen). In the sixties, this story was already so powerful that it not only influenced historiography but also acted on the construction of individual memory. Among the German public, the story of the Rosenstrasse then soon totally disappeared as the discussion surrounding the resistance during National Socialism shifted to the bürgerliche opposition. The fact that the collective memory of the protest in the Rosenstrasse was revitalized in the 1990s and even achieved something of a media boom perhaps had

125. On the assumed ending see Stolzfus, Aufstand, 32; Jochheim, Frauenprotest (1983), 138; Grunewald-Rampe, 148.

126. All of these claims are in Stoltzfus, Aufstand, 363. Stoltzfus, "Third Reich History," 681; idem, Alfstand, 341; idem, Protest, 239, 246. See also the definitive critique of Stoltzfus in Dipper, Schurerigketen mit der Resistenz, $4(19-16$. 
much to do with the new definition of the Federal Republic after the unification of both German states, but also with the interest of the internationally growing research on women, peace, and resistance. The "successful" protest of 1943 today appears increasingly as the place of memory, not only for Germans, for individual revolt and for civic courage against the NS dictatorship and its anti-Jewish policy.

In the Rosenstrasse, people protested against the very last phase of mass deportations. They did not protest against the transportations in general, but they wanted to save their Jewish relatives, who were part of a "privileged" group. It is somewhat problematic to conclude from this event that at that late point in time one could have influenced the deportation and destruction of the Jews. The majority of German Jews had long since been deported by the NS state. On the fields of murder and in the places of extermination millions of people had already died. An opposition with a chance of success would have had to be formed much earlier, in my opinion, and on a much wider scale: in 1933 against the first anti-Jewish measures and on all levels of German society.

As the research of the past decade shows, the persecution of the Jews was not a straight process undertaken from the top down. Rather the anti-Jewish policy radicalized itself in a dynamic dialectic both among the central NS institutions and between national and local levels. This opened considerable room for the offices and institutions and the people acting within them to initiate persecution as well as to block it. Rather than further subscribe to the myth of the success of the Rosenstrasse protest, it seems to be more fruitful for historical research to pay more attention to people's individual action from the beginning of the NS dictatorship on, be they planners or executioners of anti-jewish measures or their victims. On the one hand, this approach would shed light on the motives and interests of the perpetrators in all areas of NS society, and on the other, as had been shown here regarding flight and assistance of thousands of people when going underground, it would significantly widen our knowledge of unknown and successful forms of individual opposition of both Jews and Gentiles against the NS persecution of the Jews.

TECHNICAL UNIVERSITY BERLIN 